\title{
COVID-19: prevention and future initiative within nursing homes
}

\author{
Marysia Wrona \\ Laboratory for Geriatric Medicine, Department \\ and Chair of Palliative Medicine, Poznan \\ University of Medical Sciences, Poland \\ (D) https://orcid.org/0000-0003-4482-3511 \\ Corresponding author: marysia.b.wrona@gmail.com

\section{Sławomir Tobis} \\ Laboratory for Geriatric Medicine, Department \\ and Chair of Palliative Medicine, Poznan \\ University of Medical Sciences, Poland \\ (iD) https://orcid.org/0000-0002-0764-3258

\section{Katarzyna Wieczorowska-Tobis} \\ Laboratory for Geriatric Medicine, Department \\ and Chair of Palliative Medicine, Poznan \\ University of Medical Sciences, Poland \\ (iD) https://orcid.org/0000-0003-4017-3013 \\ Agnieszka Neumann-Podczaska \\ Laboratory for Geriatric Medicine, Department \\ and Chair of Palliative Medicine, Poznan \\ University of Medical Sciences, Poland \\ https://orcid.org/0000-0002-0060-7430
}

DOI: https://doi.org/10.20883/medical.e451

Keywords: long term living facilities, elderly, older individuals, SARS-CoV-2

Published: 2020-09-30

How to cite: Wrona $M$, Tobis $S$, Wieczorowska-Tobis $K$ Neumann-Podczaska A. COVID-19: prevention and future initiative within nursing homes. JMS [Internet]. 2020 Sep 30;89(3):e451. doi:10.20883/medical.e451

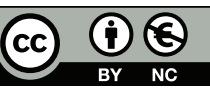

(c) 2020 by the author(s). This is an open access article distributed under the terms and conditions of the Creative Commons Attribution (CC BY-NC) licencse. Published by Poznan University of Medical Sciences

\section{ABSTRACT}

The high COVID-19 mortality rate in nursing homes in the United States and internationally prompted a comprehensive mini literature review concerning the prevalence, preventative protocol, and proactive initiatives against the highly infectious COVID-19. PubMed articles published between January and June 2020 and data sourced from government ministries of health concerning COVID-19 in nursing homes were used for this review. The prevalence and mortality rate in seven countries were compared. The underlying theme of the articles reviewed addressed four focus areas for the prevention of infectious disease spread: diagnostics, protection of residents in nursing facilities, administration and staff protection, and legislative advocacy. Adaptations and solutions may reduce the current transmission of COVID-19 within nursing homes, as well as in the future.

\section{Introduction}

An unexpected demographic group that has been significantly impacted by the coronavirus disease 2019 (COVID-19) pandemic are the elderly in nursing homes and long-term facilities. The rapid spread within a long-term skilled facility was highlighted by the first report published on $28^{\text {th }}$ February 2020 in King County, Washington [1]. For the most part, COVID-19 cases in nursing homes are related to the facility location and size, not quality metrics [2]. The illness caused by severe acute respiratory syndrome coronavirus 2 (SARS-CoV-2) affects the elderly far more severely due to the multiple comorbidities, cognitive and behavioural issues, and living situations [3]. The focus of this literature review is to highlight the prevalence and mortality rate of COVID-19 within nursing facilities, and in turn, review which preventative measures could lower the transmission of an infectious outbreak in the future. 


\section{Material and Methods}

Prevalence and mortality rates within nursing homes were collected from countries' government health ministry COVID-19 data pages. The selected countries had data on COVID-19 cases within nursing facilities.

A literature review was performed using the PubMed database, focusing on preventative measures against COVID-19 within nursing homes. The search criteria were limited to articles and data published between January 2020 to June 2020 using the following keyword(s): nursing home(s), long-term living facility, elderly, older individual(s), COVID-19, SARS-CoV-2, prevalence, mortality rate. An article was excluded if it had no substantial pro- tocol for infection prevention or failed to address the nursing facility population. Articles were selected for review if they identified an issue regarding infection spread or proposed a protocol to preserve the health of residents and the workforce.

\section{Results}

Table 1 summarises data collected from seven countries: Belgium, Spain, Germany, Singapore, Australia, Canada, and the United States. The data comprised of the number of cases and deaths in affected long-term care facilities (LTCF) and showed that the population within care facilities in these countries had been significantly affected by COVID-19, with deaths among residents

Table 1. COVID-19 cases and deaths in affected facilities that include residential care centres, long-term care facilities, and nursing homes around the world

\begin{tabular}{|c|c|c|c|c|c|c|c|}
\hline Country & $\begin{array}{l}\text { Report } \\
\text { date }\end{array}$ & Affected facilities & $\begin{array}{l}\text { Total } \\
\text { number of } \\
\text { COVID-19 } \\
\text { cases }\end{array}$ & $\begin{array}{l}\text { Confirmed } \\
\text { COVID-19 } \\
\text { cases in } \\
\text { LTCF }\end{array}$ & $\begin{array}{l}\text { COVID-19 } \\
\text { related } \\
\text { deaths in } \\
\text { LTCF }\end{array}$ & $\begin{array}{l}\text { Total } \\
\text { number of } \\
\text { COVID-19 } \\
\text { deaths }\end{array}$ & $\begin{array}{l}\text { \% of } \\
\text { LTCF } \\
\text { deaths }\end{array}$ \\
\hline $\begin{array}{l}\text { Belgium } \\
{[4]}\end{array}$ & $\begin{array}{l}15^{\text {th }} \text { June } \\
2020\end{array}$ & Residential care centres & 60,100 & N/A & 4,472 & 9,661 & $46 \%$ \\
\hline $\begin{array}{l}\text { Spain } \\
{[5]}\end{array}$ & $\begin{array}{l}15^{\text {th }} \text { June } \\
2020\end{array}$ & Residential care centres & 246,272 & $\mathrm{~N} / \mathrm{A}$ & 19,549 & 28,323 & $69 \%$ \\
\hline $\begin{array}{l}\text { Germany } \\
{[6]}\end{array}$ & $\begin{array}{l}15^{\text {th }} \text { June } \\
2020\end{array}$ & $\begin{array}{l}\text { Facilities for the care of older, dibbled, or } \\
\text { other persons in need of care, homeless } \\
\text { shelters, community facilities for asylum }\end{array}$ & 186,461 & 17,300 & 3,439 & 8,791 & $39 \%$ \\
\hline $\begin{array}{l}\text { Singapore } \\
\text { [7] }\end{array}$ & $\begin{array}{l}3^{\text {rd }} \text { May } \\
2020\end{array}$ & $\begin{array}{l}\text { LTCF run by governments, non-profit } \\
\text { organisations, and the private sector }\end{array}$ & 18,205 & $\mathrm{~N} / \mathrm{A}$ & 2 & 18 & $11 \%$ \\
\hline $\begin{array}{l}\text { Australia } \\
{[8]}\end{array}$ & $\begin{array}{l}21^{\text {st }} \text { June } \\
2020\end{array}$ & $\begin{array}{l}\text { Australian government subsidised } \\
\text { residential aged care facilities }\end{array}$ & 7,461 & 71 & 29 & 102 & $28 \%$ \\
\hline Canada [9] & $\begin{array}{l}22^{\text {nd }} \text { April } \\
2020\end{array}$ & $\begin{array}{l}\text { Long-term care or other residential care } \\
\text { settings (including retirement homes and } \\
\text { assisted living facilities) }\end{array}$ & 40,179 & 6,519 & 1,240 & 1,974 & $62 \%$ \\
\hline $\begin{array}{l}\text { United } \\
\text { States [10] }\end{array}$ & $\begin{array}{l}14^{\text {th }} \text { May } \\
2020\end{array}$ & $\begin{array}{l}\text { Medicare skilled nursing facility/Medicaid } \\
\text { nursing facility }\end{array}$ & $1,480,873$ & 107,389 & 29,497 & 89,219 & $33 \%$ \\
\hline
\end{tabular}

* official data on COVID-19 related deaths among home care residents is not available for all countries due to discrepancies among testing availability and polices in documenting deaths

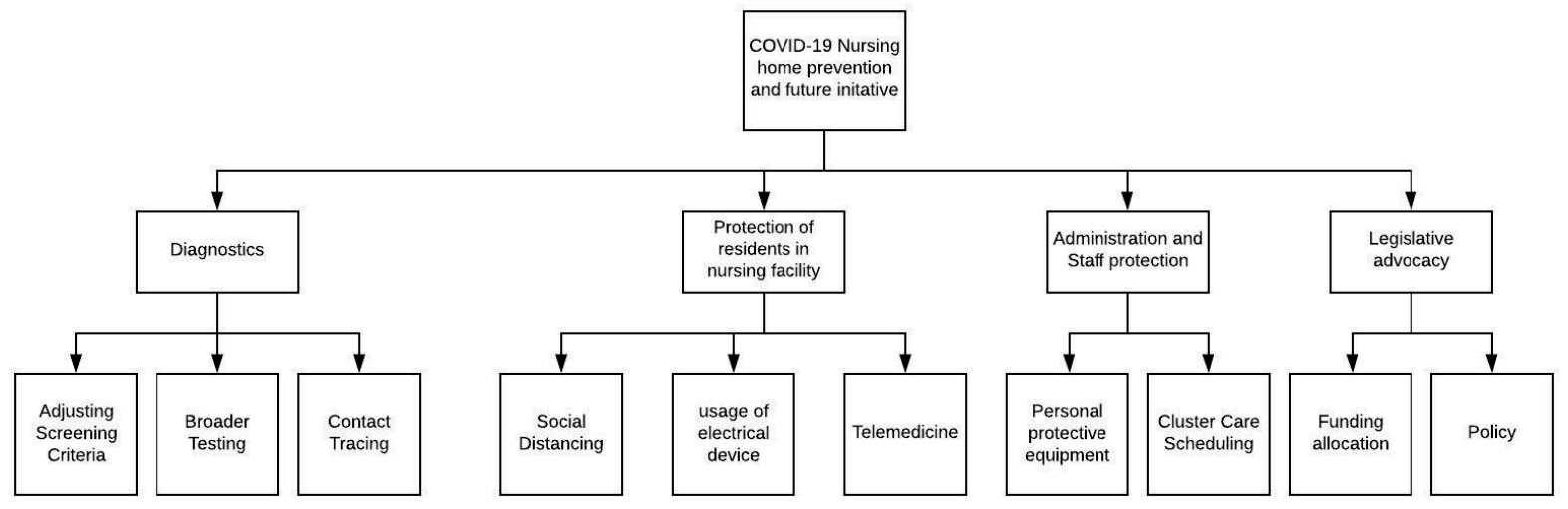

Figure 1. Summary of the nursing home preventative actions against COVID-19 based on the available studies 
Table 2. Studies associated with COVID-19 in nursing homes found through PubMed

\begin{tabular}{|c|c|c|c|c|c|}
\hline Study & Objective & Method & Preventative Action & Results & Summary \\
\hline $\begin{array}{l}\text { 三 } \\
\bar{\pi} \\
\frac{ \pm}{0} \\
\frac{\pi}{\pi} \\
\frac{\pi}{0} \\
\sum_{0}^{0} \\
\sum\end{array}$ & $\begin{array}{l}\text { Investigation of con- } \\
\text { firmed cases of COVID- } \\
19 \text { in a skilled nursing } \\
\text { facility in King County, } \\
\text { Washington on } 28^{\text {th }} \\
\text { February } 2020\end{array}$ & $\begin{array}{l}\text { Public Health-Seattle } \\
\text { and King County, aided } \\
\text { by the CDC launched } \\
\text { an investigation; con- } \\
\text { tact tracing initiated } \\
\text { where COVID-19 posi- } \\
\text { tive individuals were } \\
\text { interviewed to collect } \\
\text { information regarding } \\
\text { symptoms, severity, } \\
\text { other chronic illnesses, } \\
\text { travel history, and } \\
\text { close contacts; diag- } \\
\text { nostic testing; survey } \\
\text { to assess clusters of } \\
\text { influenza-like illness } \\
\text { among residents, staff, } \\
\text { transfers, and other fa- } \\
\text { cilities in the area; sur- } \\
\text { vey assessed issues } \\
\text { that may have contrib- } \\
\text { uted to infection } \\
\text { spread }\end{array}$ & $\begin{array}{l}\text { Diagnostic broad test- } \\
\text { ing and adjusting } \\
\text { screening criteria; ad- } \\
\text { ministration and staff- } \\
\text { ing cluster scheduling, } \\
\text { personal protective } \\
\text { equipment }\end{array}$ & $\begin{array}{l}4 \text { cases confirmed at } \\
\text { Facility A within King } \\
\text { County with } 45 \text { resi- } \\
\text { dents and staff dis- } \\
\text { playing symptoms on } \\
28^{\text {th }} \text { February } 2020 \\
\\
\text { As of } 18^{\text {th }} \text { March, } 167 \\
\text { persons positive for } \\
\text { COVID-19 linked to } \\
\text { Facility A; most indi- } \\
\text { viduals had a range of } \\
\text { symptoms besides } 7 \\
\text { cases; the mortality } \\
\text { rate was } 33.7 \% \text {; most } \\
\text { individuals had under- } \\
\text { lying chronic illnesses; } \\
3 \text { other facilities were } \\
\text { epidemiologically } \\
\text { linked to Facility A } \\
\\
\text { Survey identified that } \\
\text { vulnerability of facili- } \\
\text { ties, staff who worked } \\
\text { while symptomatic, } \\
\text { staff working in multi- } \\
\text { ple facilities, issues } \\
\text { with PPE, and delayed } \\
\text { recognition of cases }\end{array}$ & $\begin{array}{l}\text { COVID-19 rapidly } \\
\text { spreads once intro- } \\
\text { duced into a skilled } \\
\text { nursing facility, which } \\
\text { has many negative } \\
\text { consequences } \\
\text { Steps against infection } \\
\text { spread need to be im- } \\
\text { plemented quickly } \\
\text { Broad testing, staff } \\
\text { management, PPE } \\
\text { supply should be prac- } \\
\text { tised }\end{array}$ \\
\hline 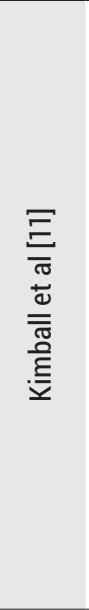 & $\begin{array}{l}\text { Investigation of as- } \\
\text { ymptomatic, presymp- } \\
\text { tomatic SARS-CoV-2 } \\
\text { cases in long-term } \\
\text { care skilled nursing fa- } \\
\text { cility }\end{array}$ & $\begin{array}{l}\text { 1st case with a long- } \\
\text { term care skilled nurs- } \\
\text { ing facility occurred on } \\
28^{\text {th }} \text { February } 2020 \\
\text { On } 13^{\text {th }} \text { March, CDC } \\
\text { performed system as- } \\
\text { sessments and SAR- } \\
\text { CoV-2 testing to as- } \\
\text { sess utilisation of } \\
\text { symptoms screen as } \\
\text { a clinical assessment } \\
\text { of COVID-19; residents } \\
\text { categorised as asymp- } \\
\text { tomatic or symptomat- } \\
\text { ic at the time of testing } \\
\text { and preceding } 14 \text { days }\end{array}$ & $\begin{array}{l}\text { Diagnostic broad test- } \\
\text { ing and adjusting } \\
\text { screening criteria }\end{array}$ & $\begin{array}{l}76 \text { of } 82 \text { residents } \\
\text { tested positive; among } \\
23(30 \%) \text { residents } \\
\text { with positive results, } \\
10(43 \%) \text { had symp- } \\
\text { toms and } 13(57 \%) \\
\text { were asymptomatic }\end{array}$ & $\begin{array}{l}\text { Symptom-based } \\
\text { screening misses the } \\
\text { identification of all } \\
\text { COVID-19 cases, even } \\
\text { a person who is as- } \\
\text { ymptomatic or pres- } \\
\text { ymptomatic can have } \\
\text { a high quantity of viral } \\
\text { RNA }\end{array}$ \\
\hline $\begin{array}{l}\text { 플 } \\
\frac{\pi}{\pi} \\
\frac{\pi}{0} \\
\frac{\pi}{0}\end{array}$ & $\begin{array}{l}\text { Investigation of con- } \\
\text { firmed cases of COVID- } \\
19 \\
\text { On } 28^{\text {th }} \text { March } 2020 \text {, } \\
\text { two residents in } \\
\text { a long-term care } \\
\text { skilled nursing facility } \\
\text { at Veterans Affairs } \\
\text { Greater Lost Angeles } \\
\text { Healthcare System } \\
\text { had positive test re- } \\
\text { sults for COVID-19 }\end{array}$ & $\begin{array}{l}\text { During } 29^{\text {th }} \text { March } 29- \\
23^{\text {rd }} \text { April, all staff and } \\
\text { residents were tested } \\
\text { every week by reverse } \\
\text { transcription-poly- } \\
\text { merase chain reaction } \\
\text { (RT-PCR) testing of } \\
\text { nasopharyngeal speci- } \\
\text { mens }\end{array}$ & $\begin{array}{l}\text { Diagnostics broad } \\
\text { testing and contact } \\
\text { tracing }\end{array}$ & $\begin{array}{l}99 \text { residents }(19 \%) \text { and } \\
\text { eight of } 136(6 \%) \text { staff } \\
\text { members tested posi- } \\
\text { tive; isolation protocol } \\
\text { implemented; addi- } \\
\text { tional testing on } 13^{\text {th }} \text {, } \\
22^{\text {nd }} \& 23^{\text {rd }} \text { April } \\
\text { showed no new posi- } \\
\text { tive cases }\end{array}$ & $\begin{array}{l}\text { Broad testing of resi- } \\
\text { dents and staff mem- } \\
\text { bers of a long-term } \\
\text { care skilled nursing fa- } \\
\text { cility aided in the rapid } \\
\text { identification of } \\
\text { hotspots } \\
\text { Isolation and grouping } \\
\text { of these residents lead } \\
\text { to a reduction in trans- } \\
\text { mission within the fa- } \\
\text { cility } \\
\text { Serial testing of resi- } \\
\text { dents performed until } \\
\text { all were negative }\end{array}$ \\
\hline
\end{tabular}


Table 2. Continued

\begin{tabular}{|c|c|c|c|c|c|}
\hline Study & Objective & Method & Preventative Action & Results & Summary \\
\hline 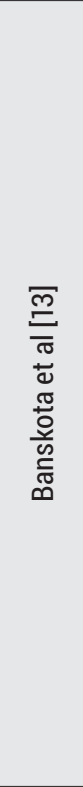 & $\begin{array}{l}\text { Show benefits of using } \\
\text { mobile technology } \\
\text { such as application to } \\
\text { better quality of life } \\
\text { during isolation of old- } \\
\text { er adults }\end{array}$ & $\begin{array}{l}\text { Apps review categor- } \\
\text { ised as: social net- } \\
\text { working, medical, } \\
\text { health and fitness, } \\
\text { food and drinks, and } \\
\text { visual and hearing } \\
\text { Apps needed a rating } \\
\text { of } 4.5 \text { or higher and at } \\
\text { least } 3000 \text { reviews in } \\
\text { the Apple Store } \\
\text { Further screened } \\
\text { based on function, } \\
\text { cost, and ranking } \\
\text { based on reviews }\end{array}$ & $\begin{array}{l}\text { Protection of residents } \\
\text { within the nursing fa- } \\
\text { cility through the use } \\
\text { of electrical devices }\end{array}$ & $\begin{array}{l}\text { Top apps } \\
\text { social networking: } \\
\text { Facetime and Skype } \\
\text { medical: } \\
\text { telemedicine (Teladoc, } \\
\text { K Health Primary Care, } \\
\text { Doctor on Demand), } \\
\text { prescription manage- } \\
\text { ment (GoodRx, } \\
\text { Medisafe medication } \\
\text { management) } \\
\text { health and fitness: } \\
\text { calm, headspace, } \\
\text { MyFitnessPal, and } \\
\text { Yoga: down dog } \\
\text { food and drinks: } \\
\text { Doordash and } \\
\text { Instacart } \\
\text { visual and hearing: Be } \\
\text { my eyes- helping blind } \\
\text { and Glide-live video } \\
\text { messenger }\end{array}$ & $\begin{array}{l}\text { Many apps available } \\
\text { on many mobile device } \\
\text { platforms can help } \\
\text { older adults handle } \\
\text { isolation by staying } \\
\text { connected with others } \\
\text { and maintain autono- } \\
\text { my }\end{array}$ \\
\hline 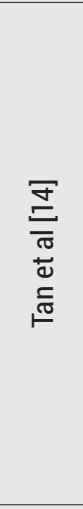 & $\begin{array}{l}\text { In Singapore, deaths of } \\
\text { LTCF residents due to } \\
\text { COVID-19 accounted } \\
\text { for } 14 \% \text { of total fatali- } \\
\text { ties as of } 14^{\text {th }} \text { April } \\
2020\end{array}$ & $\begin{array}{l}\text { Following preventative } \\
\text { strategies implement- } \\
\text { ed rapidly across all } \\
\text { LTCF: early manage- } \\
\text { ment of LTCF residents } \\
\text { with respiratory symp- } \\
\text { toms, transfer proto- } \\
\text { cols between hospital } \\
\text { and LTCF, increased } \\
\text { temperature screen- } \\
\text { ing, restriction of visi- } \\
\text { tors, social distancing, } \\
\text { and segregation of } \\
\text { staff and residents }\end{array}$ & $\begin{array}{l}\text { Administration and } \\
\text { staffing cluster sched- } \\
\text { uling, personal protec- } \\
\text { tive equipment }\end{array}$ & $\begin{array}{l}\text { After a month, COVID- } \\
19 \text { found in } 6 \text { nursing } \\
\text { homes in Singapore; } \\
\text { an increase in LTCF } \\
\text { correlated with expo- } \\
\text { nential community } \\
\text { transmission meaning } \\
\text { staff were at risk of } \\
\text { catching the virus and } \\
\text { spreading it to the res- } \\
\text { idents }\end{array}$ & $\begin{array}{l}\text { Staff management is } \\
\text { very important in pre- } \\
\text { venting the spread of } \\
\text { infection }\end{array}$ \\
\hline 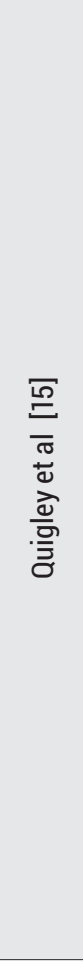 & $\begin{array}{l}\text { Preparedness of } \\
\text { Nursing Homes across } \\
\text { the nation }\end{array}$ & $\begin{array}{l}\text { Emailed a } 30 \text {-item sur- } \\
\text { vey to } \mathrm{NH} \text { drawn from } \\
\text { national surveys con- } \\
\text { ducted in } 2013 \text { and } \\
2015(\mathrm{~N}=942) \text {; first } \\
\text { email sent on } 30^{\text {th }} \\
\text { March } 2020 \text { and re- } \\
\text { minder on } 5^{\text {th }} \text { April } \\
2020\end{array}$ & $\begin{array}{l}\text { Administration and } \\
\text { staff personal protec- } \\
\text { tive equipment and } \\
\text { legislative allocation } \\
\text { of funds }\end{array}$ & $\begin{array}{l}\text { Fifty-six NH responded } \\
\text { nationwide, represent- } \\
\text { ing } 29 \text { states within } \\
\text { the United States } \\
\text { Guidance and } \\
\text { Preparedness: } \\
\text { NH used } 2-5 \text { guidance } \\
\text { documents by CDC, } \\
\text { WHO, local govern- } \\
\text { ment } \\
\text { Greatest COVID-19 } \\
\text { preparedness concern: } \\
\text { lack of supplies (43\%), } \\
\text { especially PPE, staff } \\
\text { shortages (34\%), and } \\
\text { resident health and } \\
\text { safety ( } 14 \%) \\
\text { Financial effects: } \\
\text { most indicated in- } \\
\text { creased costs for sup- } \\
\text { plies ( } 58 \% \text { and em- } \\
\text { ployee hours ( } 38 \%), \text { or } \\
\text { fewer admissions } \\
(27 \%)\end{array}$ & $\begin{array}{l}\text { Results indicate fur- } \\
\text { ther need for NHS to } \\
\text { continue prepared- } \\
\text { ness, with a particular } \\
\text { focus on the lack of } \\
\text { supplies, especially } \\
\text { PPE }\end{array}$ \\
\hline
\end{tabular}


accounting for $11-69 \%$ of all COVID-19 related deaths (Table 1). Of the seven countries, Spain had the highest percentage of LTCF deaths, with the percentage of deaths in LTCF in Belgium, Germany, Australia, and the United States between $28-45 \%$, highlighting the vulnerability of LTCF communities. Examples of effective preventative measures can be drawn from Singapore, where the percentage of deaths in LTCF was $11 \%$.

Sixty-two articles matched keywords, but only six articles are summarised in Table 2, and Figure 1 quantitively addresses COVID-19 issues within nursing homes and provides preventative guidelines.

\section{Discussion}

The purpose of this literature review was to comprehensively address the high number of cases and deaths within nursing homes, the issue of infection prevention, and future mitigation of infectious spread. The underlying theme of the articles addressed four areas: diagnostics, protection of residents in nursing facilities, administration and staff protection, and legislative advocacy.

\section{Diagnostics}

The initial screening for COVID-19 is usually based on clinical presentation, with the most common symptoms being fever, cough, and shortness of breath [11]. Many elderly individuals present with atypical symptoms of satiety or altered mental status that can be confused as a symptom of age or a chronic illness [16]. Adjusting the screening criteria for COVID-19 to include these atypical symptoms needs to be implemented for the timely identification of cases. Furthermore, asymptomatic individuals can also have a high viral load [11]. Broad facility testing and serial testing of residents and staff should be implemented to identify clusters of infection [12], as the early identification of hotspots and initiation of infection protocols can significantly reduce the transmission within facilities [12]. Furthermore, an investigation of positive individuals can help identify weaknesses in the prevention protocol.

\section{Protection of residents in nursing facilities} COVID-19 can rapidly spread among residents and staff once introduced into a skilled nursing facility, which may have many negative con- sequences. Hence, many facilities implemented social distancing to slow down the communicable spread of COVID-19, with residents isolated from each other, restricted family visitation, and limited interaction with staff [12]. Though isolation reduces the spread of infection, it has some negative ramifications. The loss of communication with others, especially loved ones, lack of information, and loss of autonomy can psychologically impact a resident in a nursing home leading to depression [13]. However, the use of devices can help address this issue, as various apps that focus on social networking, telemedicine, prescription management, health and fitness, and food and drink can be utilised to improve the residents' quality of life [13]. Many residents of nursing homes are considered vulnerable COVID-19 due to their underlying health conditions, so telemedicine can be used to provide continuity of care by limiting the cross interaction with health care providers that may have been exposed to COVID-19 [16].

\section{Administration and Staff Protection}

Staff management is essential in preventing the spread of infection, as there is the potential for staff to acquire the virus through community transmission, then spread it to the facility residents [14]. To minimise cross interaction between residents and their multidisciplinary care team, cluster care scheduling of staff should be implemented whereby the staff are assigned to specific patients for the duration of their shift [17]. To protect the staff members who are putting themselves at risk, an adequate supply of personal protective equipment and additional resources need to be accessible. In addition, if the supply chain is limited, staff need to be educated on how to reuse resources throughout their shift in a safe manner [15].

\section{Legislative advocacy}

Unfortunately, often the elderly demographic is forgotten during a health crisis, therefore, emphasis needs to be placed on public health planning by collaborating with geriatric health experts, nursing home leadership, and government [18]. Reform and policies focusing on funding allocation need to be made so that resources, like personal protective gear, testing supplies, wages for increased staff, and smart device purchases, can be used within a nursing home to minimise the negative outcomes of an infectious outbreak. 
If implemented, the above solutions can reduce the transmission of COVID-19 and help prepare facilities for future outbreaks.

\section{Acknowledgements}

\section{Conflict of interest statement}

The authors declare no conflict of interest.

\section{Funding sources}

There are no sources of funding to declare.

\section{References}

1. McMichael TM, Currie DW, Clark S, Pogosjans S, Kay M, Schwartz NG, Lewis J, Baer A, Kawakami V, Lukoff MD, Ferro J, Brostrom-Smith C, Rea TD, Sayre MR, Riedo FX, Russell D, Hiatt B, Montgomery P, Rao AK, Chow EJ, Tobolowsky F, Hughes MJ, Bardossy AC, Oakley LP, Jacobs JR, Stone ND, Reddy SC, Jernigan JA, Honein MA, Clark TA, Duchin JS. Epidemiology of Covid-19 in a Long-Term Care Facility in King County, Washington. New England Journal of Medicine. 2020 May 21;382(21):2005-2011. https://doi.org/10.1056/ nejmoa2005412

2. Abrams HR, Loomer L, Gandhi A, Grabowski DC. Characteristics of U.S. Nursing Homes with COVID-19 Cases. Journal of the American Geriatrics Society. $2020 \mathrm{Jul}$ 7;68(8):1653-1656. https://doi.org/10.1111/jgs.16661

3. Cohen MA, Tavares J. Who are the Most At-Risk Older Adults in the COVID-19 Era? It's Not Just Those in Nursing Homes. Journal of Aging \& Social Policy. 2020 May 17;32(4-5):380-386. https://doi.org/10.108 $0 / 08959420.2020 .1764310$

4. 19 -Epidemiologische situatie: Coronavirus COVID-19. https://covid-19.sciensano.be/nl/covid-19-epidemiologische-situatie. Accessed 2020 June 22.

5. Radiografía del coronavirus en residencias de ancianos en España. https://www.rtve.es/ noticias/20200624/radiografia-del-coronavirusresidencias-ancianos-espana/2011609.shtml. Accessed 2020 June 22.

6. Coronavirus Disease 2019 (COVID-19) Daily situation report of the Robert Koch Institute. https:// www.rki.de/DE/Content/InfAZ/N/Neuartiges_Coronavirus/Situationsberichte/2020-06-15-en.pdf? blob=publicationFile. Accessed 2020 June 15.

7. Tan $L$, Seetharaman S. COVID-19 outbreak in nursing homes in Singapore. https://www.ncbi.nlm.nih.gov/ pmc/articles/PMC7219412. Accessed 2020 June 15.

8. Coronavirus (COVID-19) current situation and case numbers. https://www.health.gov.au/news/healthalerts/novel-coronavirus-2019-ncov-health-alert/ coronavirus-covid-19-current-situation-and-casenumbers. Accessed 2020 June 15

9. Hsu A, Lane N. Impact of COVID-19 on residents of Canada's long-term care homes - ongoing challenges and policy response. https://ltccovid.org/2020/04/15/ impact-of-covid-19-on-residents-of-canadas-long- term-care-homes-ongoing-challenges-and-policyresponse. Accessed 2020 June 15.

10. COVID-19 Nursing Home Data. https://data.cms. gov/stories/s/COVID-19-Nursing-Home-Data/bkwzxpvg. Accessed 2020 June 15.

11. Kimball A, Hatfield KM, Arons M, James A, Taylor J, Spicer K, Bardossy AC, Oakley LP, Tanwar S, Chisty Z, Bell JM, Methner M, Harney J, Jacobs JR, Carlson CM, McLaughlin HP, Stone N, Clark S, BrostromSmith C, Page LC, Kay M, Lewis J, Russell D, Hiatt B, Gant J, Duchin JS, Clark TA, Honein MA, Reddy SC, Jernigan JA, Baer A, Barnard LM, Benoliel E, Fagalde MS, Ferro J, Smith HG, Gonzales E, Hatley N, Hatt G, Hope $M$, Huntington-Frazier M, Kawakami V, Lenahan JL, Lukoff MD, Maier EB, McKeirnan S, Montgomery P, Morgan JL, Mummert LA, Pogosjans S, Riedo FX, Schwarcz L, Smith D, Stearns S, Sykes KJ, Whitney H, Ali H, Banks M, Balajee A, Chow EJ, Cooper B, Currie DW, Dyal J, Healy J, Hughes M, McMichael TM, Nolen L, Olson C, Rao AK, Schmit K, Schwartz NG, Tobolowsky F, Zacks R, Zane S. Asymptomatic and Presymptomatic SARS-CoV-2 Infections in Residents of a Long-Term Care Skilled Nursing Facility - King County, Washington, March 2020. MMWR. Morbidity and Mortality Weekly Report. 2020 Apr 3;69(13):377381. https://doi.org/10.15585/mmwr.mm6913e1

12. Dora AV, Winnett A, Jatt LP, Davar K, Watanabe M, Sohn L, Kern HS, Graber CJ, Goetz MB. Universal and Serial Laboratory Testing for SARS-CoV-2 at a LongTerm Care Skilled Nursing Facility for Veterans Los Angeles, California, 2020. MMWR. Morbidity and Mortality Weekly Report. 2020 May 29;69(21):651655. https://doi.org/10.15585/mmwr.mm6921e1

13. Banskota S, Healy M, Goldberg E. 15 Smartphone Apps for Older Adults to Use While in Isolation During the COVID-19 Pandemic. WestJEM 21.3 May Issue. $2020 \mathrm{Apr}$ 14;21(3). https://doi.org/10.5811/ westjem.2020.4.47372

14. Tan LF, Seetharaman SK. COVID-19 outbreak in nursing homes in Singapore. Journal of Microbiology, Immunology and Infection. 2020 May; https://doi. org/10.1016/j.jmii.2020.04.018

15. Quigley DD, Dick A, Agarwal M, Jones KM, Mody L, Stone PW. COVID-19 Preparedness in Nursing Homes in the Midst of the Pandemic. Journal of the American Geriatrics Society. 2020 May 12;68(6):1164-1166. https://doi.org/10.1111/jgs.16520

16. Munanga A. Critical Infection Control Adaptations to Survive COVID-19 in Retirement Communities. Journal of Gerontological Nursing. 2020 Jun 1;46(6):3-5. https://doi.org/10.3928/00989134-20200511-03

17. Cormi C, Chrusciel J, Laplanche D, Dramé M, Sanchez $\mathrm{S}$. Telemedicine in nursing homes during the COVID-19 outbreak: A star is born (again). Geriatrics \& Gerontology International. 2020 May 27;20(6):646647. https://doi.org/10.1111/ggi.13934

18. American Geriatrics Society Policy Brief: COVID-19 and Nursing Homes. Journal of the American Geriatrics Society. 2020 Apr 29;68(5):908-911. https://doi. org/10.1111/jgs.16477 